\title{
Different Paths For Words and Money: The Semantic Field of "Commerce and Finance" in Middle English
}

\author{
Isabel Moskowich and Begoña Crespo \\ University of A Coruña
}

\begin{abstract}
Our aim in this paper is to examine the relationship between society and language change. Developments such as the discovery of new territories and the introduction of new and exotic products and practices are known to have caused a significant increase in the number of terms with economic nuances from the sixteenth century onwards. We believe that the economy is a good indicator of relations among different groups of people and of the way in which those relations contributed to the evolution of language even from the early stages, a conclusion we base on the etymological origin of specialised terms introduced during Middle English.
\end{abstract}

\section{Introduction}

The main purpose of this paper is to investigate the relationship, if any, between the frequency of terms relating to trade and finance and their etymological origin over a period in the history of the English language prior to what is referred to as the Early Modern English period, throughout which commercial relations between England and other countries were intense. The first part of this study will be concerned with the historical events and other external factors which may have brought about the expansion of vocabulary relating to commerce. Our aim is to examine the relationship between society and language change. Developments such as the discovery of new territories and the introduction of new and exotic products are known to have caused a significant increase in the number of terms with 
economic nuances from the sixteenth century onwards. Less attention, however, has been paid to what may have happened immediately before this period, that is to say, in Middle English.

The survey proposed here will be carried out within the theoretical framework of Historical Sociolinguistics. As Nevalainen and Raumolin-Brunberg (2005: 34) have put it: “...the social factors affecting linguistic variation have also become the focus of interest in their own right, despite the problems researchers encounter in reconstructing the social realities their informants lived in". They insist that the external circumstances restricting linguistic variation "will have to be reconstructed on the basis of what we know about the past societies themselves". In this respect, it is most important to bear in mind that results obtained in this type of analysis are always biased because we can only measure the written evidence of the speech community, not the actual performance itself. Results, therefore, will be partial only.

Having looked at the historical background, section 3 will be devoted to describing our corpus of data. We will refer primarily to the samples of ME contained in the Helsinki Corpus of English Texts. Diachronic and Dialectal ( $H C$ henceforth). As we will see, the criteria followed include the need to deal with all text-types ${ }^{1}$ as well as all varieties of English in a period characterised by its high dialectal diversity. Once the data have been established, the next section (4) will focus on analysing the terms selected using various computer resources. The above-mentioned analysis revolves around two main axes, etymological and chronological. Finally, section 5 will deal with the conclusions obtained from our examination of the data. The relationship between etymological origin and frequency of occurrence will demonstrate that the history of the vocabulary of a language is inextricably related to the historical heterogeneity of the different peoples implicated in the life of that language.

From a social point of view, the field of "commerce and finance" represents an activity which called for linguistic interaction and mutual intelligibility since the exchange of products among speakers of different languages could not be effective without mutual understanding. In addition, exchange with foreign countries was

\footnotetext{
${ }^{1}$ What was referred to as "text-types" at the moment the $H C$ was published would now probably be described as "genres".
} 
necessary more often than not in a society which was increasingly urbanised and money-based. Therefore, economy can be regarded as a good indicator of relations among groups of people and the way in which their relations contribute to the evolution of language.

\section{The socio-historical background of Middle English}

The fact that "language does not exist in a vacuum; [but] it is used in concrete cultural and historical circumstances" (Anttila 1989: 377) opens the way for a simultaneous study of culture, historical events and language changes in terms of the established relationship among them. External factors give rise to internal language changes (Fernández 1993; Millward 1996; Thomason 1997; Hughes 2000; Nevalainen and Raumolin-Brunberg 2003, 2005), especially in certain fields which are quicker to feel the influence of these exogenous circumstances. As some scholars have already pointed out, the vocabulary of a language is the subsystem which best mirrors the relationship between language and society (Leith 1983; Su Jinzhi 1992, Tejada Caller 1999). In Knapp's words (2000: 8), “... close attention to the range and tone of words is important evidence of how social change is being naturalized into the life-worlds of men and women, and therefore how tightly linguistic and social histories are woven together".

Social, economic, political and demographic events in the period concerning us (the second migration of the Vikings, the Norman Conquest, the religious movement of Wycliffe and the Lollards, The Black Death, The Peasants' Revolt, The Hundred Years War, taxation and commercial transactions with other countries) took on a new significance in the development of the English lexicon from the beginning to the end of the Middle Ages. As we will see, each event can be linked to developments in separate linguistic strata.

The successive waves of Scandinavian migrations to England began in the eighth century. However, the massive arrival of Old Norse speakers to the Isles took place from the tenth century onwards and began on the eastern coast. Though the first of these speakers had arrived some three centuries earlier, the real linguistic effects were not appreciated until the eleventh century (Moskowich 1995). In fact, from the eighth up to the beginning of the eleventh century very few loans are apparent. Most of them are of a miscellaneous character to 
designate types of ships or to refer to people, along with a number of other social and legal terms. From the beginning of the eleventh century until the middle of the twelfth century we encounter Scandinavian terms relating to the sea, social life, law, commonplace objects and even trade (toft "plot of land", bond "tie", knife, call, mal "payment", coup "buy", scogh "wood", marc "money", thrift "material wealth"). During the ME period, dialectal variation also accounts for the greater or lesser presence of Scandinavian borrowings. Naturally, documents and literature from the northern region contain many more Norse and Danish elements than those in the south.

The Latin substratum, meanwhile, can be accounted for by the Norman Conquest on the one hand, and by the pervasive effect of Christianisation in the spheres of art and learning, on the other. ${ }^{2}$ Some examples of this contact include: intellect, mechanical, secular, submit, testify, zenith.

After the Norman Conquest (1066) another foreign language left its mark on the vernacular. The language of prestige and power in England from the twelfth to the fourteenth century was to be Norman French. Contacts between the two peoples resulted in a linguistic hybrid known as Anglo-French or Anglo-Norman, which became the official language of justice, politics and the court, not the language of everyday speech among the conquered. This peculiar relationship between the two peoples is reflected in the different semantic fields to which loanwords belong. Written records from the eleventh century provide few examples of loans; they become more numerous from the twelfth century onwards. According to Serjeantson (1935: 216-239) they cover the following fields: person-rank, finance, buildings, law, social relations, religion, military, nature, clothes, household objects, physical action, appearance, faculty, moral and intellectual and miscellaneous.

In texts from the centuries that followed, the presence of technical, religious, abstract and learned terms is more pronounced. French loanwords in English convey so many different shades of meaning that some scholars (Serjeantson 1935) have found it

\footnotetext{
${ }^{2}$ We will not look into the earlier contact between the inhabitants of England and Latin speakers from before Christianisation because the inhabitants of England at that stage did not speak English.
} 
necessary to include a further subdivision of the moral and intellectual field. ${ }^{3}$

Though the ascription to different semantic fields of Scandinavian and French loans may appear unbalanced, an explanation can be sought in the socio-external context. The Scandinavian population intermingled with the natives thereby precluding many terms from being considered specialised. When Scandinavians finally decided to settle in England, they did so in places already inhabited by an English-language speech community (Moskowich 2002). The coexistence of both peoples led to the assimilation of linguistic habits because of the similarity between the two languages and so the native speech community adopted Scandinavian terms without feeling they were foreign (Moskowich 1995). This was the case for very basic terms such as take, both and are. The Normans' attitude towards the native population was completely different. The relationship between the two peoples was not established on equal terms. For at least a century the linguistic effect was that French terms were regarded as exclusive to certain spheres of life and semantic fields because far from integrating into ordinary English life, the Normans kept linguistically aloof, thereby compounding the low degree of genetic relation between the NormanFrench and the English.

Historical events also indicate close relations between English and other languages. The lexicon of Middle English adopted examples of Flemish and Dutch (mart "market", pickle, guilder). Common interests were mainly commercial (handicraft, merchants, sheep, wool, fishermen, profit, ryche, pore, stor, wage), sometimes military (in times of war), and later, in the sixteenth century, religion and art served as contact-points.

Occasionally, language can function as a tool to reveal the way in which society developed. We know, for example, that commercial contact with the Germans was based on the exchange of minerals and money because terms originating in High German abound in the field of mineralogy (zinc, nickel). As Crespo (2000: 31) points out, other languages such as Arabic (maravedi, amber, cotton), Celtic (quay, vassal), and even Indian (pepper, ginger) and Semitic

\footnotetext{
${ }^{3}$ Baugh and Cable (1993) provide extensive lists of vocabulary items which were borrowed from different linguistic strata, especially from Latin and French.
} 
dialects (emerald, coral) can be said to have left an imprint on the vocabulary of trade affairs in English during the fourteenth and fifteenth centuries as a result of cultural and commercial contacts.

\section{Corpus material}

Here we present the empirical research data that have led us to some general conclusions about the semantic field of commerce and finance during the Middle Ages.

The data we will be using for this analysis are taken from the Helsinki Corpus of English Texts (1991). Since the HC is mainly a diachronic corpus, all periods of the history of the English language are represented there. However, we will focus on Middle English, the period the $H C$ compilers situate between 1150 and 1500. All the texts contained in the above-mentioned corpus are classified by means of COCOA headers according to a number of different parameters of information. For our analysis we will draw on two of these parameters: date and text-type. With respect to date, the $H C$ makes an additional division within each of the traditionally accepted periods of the history of the English language, establishing a total of four subperiods for the Middle English period:

M1: 1150-1250;

M2: 1250-1350;

M3: 1350-1420;

M4: 1420-1500.

Another decision adopted by the compilers of the $H C$ was to add information about the type of text each of the samples recorded is taken from. In the interests of uniformity, we have selected samples containing between 2000 and 2500 words from all the text-types included in each of the four sub-periods. This makes a total of 102,182. Table 1 below illustrates the different types of text represented in each of the sub-periods since not all of them appear all of the time. 
Table 1. Number of words from each sample according to period and text-type

\begin{tabular}{|c|c|c|c|}
\hline PERIOD & TEXT-TYPE & TITLE & WORDS \\
\hline ME I & Handbooks & PERI DIDAXEON & 2121 \\
\hline 1150 & Philosophy & VESPASIAN HOMILIES, NO. III < sample & 1949 \\
\hline 1250 & & & \\
\hline & Homilies & ORM, THE ORMULUM & 2196 \\
\hline & $\begin{array}{l}\text { Religious } \\
\text { treatises }\end{array}$ & HISTORY OF THE HOLY ROOD-TREE & 2111 \\
\hline & History & LAYAMON <sample 1> & 2112 \\
\hline & $\begin{array}{l}\text { Biography, } \\
\text { lives }\end{array}$ & KATHERINE < sample 1> & 2148 \\
\hline ME II & Documents & THE PROCLAMATION OF HENRY III & 362 \\
\hline 1250 & Homilies & KENTISH SERMONS & 2193 \\
\hline & $\begin{array}{l}\text { Religious } \\
\text { treatises }\end{array}$ & DAN MICHEL, AYENBITE OF INWYT & 2152 \\
\hline & History & ROBERT OF GLOUCESTER & 2152 \\
\hline & Biography, & THE LIFE OF ST. EDMUND (THE & 2152 \\
\hline & lives & $\begin{array}{llll}\text { EARLY } & \text { SOUTH } & - & \text { ENGLISH } \\
\text { LEGENDARY) } & & \end{array}$ & \\
\hline & Fiction & DAME SIRITH; INTERLUDE & 2149 \\
\hline & Romances & $\begin{array}{l}\text { THE ROMANCE OF SIR BEUES OF } \\
\text { HAMTOUN }\end{array}$ & 2164 \\
\hline & Bible & $\begin{array}{l}\text { THE EARLIEST COMPLETE ENGLISH } \\
\text { PROSE PSALTER }\end{array}$ & 2009 \\
\hline & Undefined & SONG OF THE HUSBANDMAN & 608 \\
\hline & & $\begin{array}{llll}\text { SATIRE } & \text { ON } & \text { THE } & \text { CONSISTORY } \\
\text { COURTS } & & & \end{array}$ & 602 \\
\hline & & SATIRE ON THE RETINUES & 337 \\
\hline MEIII & Documents & USK, APPEAL(S) & 2220 \\
\hline $\begin{array}{l}1350 \\
1420\end{array}$ & $\begin{array}{l}\text { Handbook, } \\
\text { astronomy }\end{array}$ & $\begin{array}{l}\text { CHAUCER, A TREATISE ON THE } \\
\text { ASTROLABE }\end{array}$ & 2213 \\
\hline & $\begin{array}{l}\text { Handbooks, } \\
\text { medicine }\end{array}$ & $\begin{array}{l}\text { A LATE MIDDLE ENGLISH TREATISE ON } \\
\text { HORSES }\end{array}$ & 2353 \\
\hline & Science, medicine & ALATINTECHNICALPHLEBOTOMY & 2126 \\
\hline & Philosophy & CHAUCER,BOETHIUS & 2374 \\
\hline & Homilies & THENORTHERNHOMILYCYCLE & 2155 \\
\hline & Sermons & ENGLISHWYCLIFFITESERMONS & 2146 \\
\hline & Rules & THEBENEDICTINERULE & 2187 \\
\hline & Religious treatises & THEPRICKEOFCONSCIENCE & 2343 \\
\hline & History & CURSORMUNDI <sample 1>, <sample $2>$ & 2315 \\
\hline & Travelogue & MANDEVILLESTRAVELS & 2141 \\
\hline
\end{tabular}




\begin{tabular}{|c|c|c|c|}
\hline \multirow[t]{4}{*}{ PERIOD } & TEXT-TYPE & TITLE & WORDS \\
\hline & Fiction & $\begin{array}{l}\text { CHAUCER, THE GENERAL PROLOGUE } \\
\text { TOTHECANTERBURYTALES }\end{array}$ & 2150 \\
\hline & \multirow{2}{*}{$\begin{array}{l}\text { Letters, non-private } \\
\text { Bible }\end{array}$} & HENRY V,LETTERLETTER(S),LONDON & 2433 \\
\hline & & THEOLDTESTAMENT(WYCLIFFE) & 2080 \\
\hline \multirow{22}{*}{$\begin{array}{l}\text { MEIV } \\
1420 \\
1500\end{array}$} & \multirow{3}{*}{$\begin{array}{l}\text { Law } \\
\text { Documents }\end{array}$} & STATUTES(II) & 2374 \\
\hline & & INDENTURE, $\quad$ PETITIONS & 2298 \\
\hline & & SHILLINGFORD(DOCUMENTS) & \\
\hline & $\begin{array}{l}\text { Handbooks, } \\
\text { medicine }\end{array}$ & $\begin{array}{l}\text { THE LIBER DE DIVERSIS MEDICINIS' IN } \\
\text { THETHORNTONMS }\end{array}$ & 2230 \\
\hline & Handbooks, other & REYNES,THECOMMONPLACEBOOK & 2302 \\
\hline & $\begin{array}{l}\text { Handbook, } \\
\text { astronomy }\end{array}$ & METHAM,DAYSOFTHEMOON & 2210 \\
\hline & \multirow{2}{*}{$\begin{array}{l}\text { Science, medicine } \\
\text { Sermons }\end{array}$} & THECYRURGIEOFGUYDECHAULIAC & 2193 \\
\hline & & $\begin{array}{l}\text { MIDDLE ENGLISH } \quad \text { SERMONS... } \\
\text { ROYAL }\end{array}$ & 2264 \\
\hline & \multirow[t]{2}{*}{ Rules } & AELRED OF RIEVAULX'S & 1846 \\
\hline & & INSTITUTIONEINCLUSARUM & \\
\hline & Religious treatises & $\begin{array}{l}\text { KEMPE, THE BOOK OF MARGERY } \\
\text { KEMPE }\end{array}$ & 2331 \\
\hline & Prefaces & $\begin{array}{l}\text { CAXTON, THE PROLOGUES AND } \\
\text { EPILOGUES }\end{array}$ & 2029 \\
\hline & $\begin{array}{l}\text { Proceed, } \\
\text { depositions }\end{array}$ & DEPOSITIONS & 1975 \\
\hline & \multirow[t]{2}{*}{ History } & GREGORY, $\quad$ THE $\quad$ HISTORICAL & 2136 \\
\hline & & $\begin{array}{l}\text { COLLECTIONS OF A CITIZEN OF } \\
\text { LONDON }\end{array}$ & \\
\hline & \multirow{2}{*}{$\begin{array}{l}\text { Biography, lives } \\
\text { Fiction }\end{array}$} & THELIFEOFST.EDMUND & 2078 \\
\hline & & $\begin{array}{l}\text { CAXTON, THE HISTORY OF REYNARD } \\
\text { THEFOX }\end{array}$ & 2098 \\
\hline & Romances & THESIEGEOFJERUSALEMINPROSE & 2218 \\
\hline & $\begin{array}{l}\text { Drama, } \mathrm{n} \\
\text { plays }\end{array}$ & LUDUSCOVENTRIAE & 2337 \\
\hline & Letters, private & SHILLINGFORD(LETTERS) & 2135 \\
\hline & \multirow{2}{*}{$\begin{array}{l}\text { Letters, non-private } \\
\text { Bible }\end{array}$} & PASTON,WILLAM & 2198 \\
\hline & & $\begin{array}{l}\text { ROLLE, THE PSALTER OF PSALMS OF } \\
\text { DAVID }\end{array}$ & 2177 \\
\hline
\end{tabular}

As the table illustrates, the earlier sub-periods exhibit fewer types than the more recent ones which is consistent with the general scarcity of written texts immediately after the Conquest. 
Since our main interest is to examine the evolution of terms relating to the sphere of commerce and finance, we have decided to limit the scope of our analysis to nouns. In his doctoral dissertation about the diachronic semantic classification of religious vocabulary in English, Chase (1988) affirms that, for religious vocabulary at least, nouns are the most important part of speech semantically. Since language uses verbs to represent states and events, and nouns to embody things, and most vocabulary items denote things, nouns are the part of speech with semantic primacy. Room (1991) argues the same principle. ${ }^{4}$

\section{Data retrieval and analysis}

From the 102,182 words that form our corpus we have selected those corresponding to the nominal category $(17,945$ or $17.56 \%)$ of which $234(1.3 \%)$ belong to the semantic field of "commerce and finance". Almost half of these occurrences (140) appear in the last sub-period between 1420 and 1500. This gives us an idea of the use of financial terms increasing in parallel with the rate of social evolution. In search of some explanation for the scarcity of financial vocabulary in the earlier sub-periods, we might reflect on all the historical events mentioned in section 1 . The persistence of the feudal system, for example, restrained the possibility of economic expansion, which only began after feudalism had faded away and the urbanisation process gradually taken root.

As we see in Graph 1 below, the semantic field of "commerce and finance" is represented in all the selected sub-periods:

\footnotetext{
4 The same theory is also subscribed to by Halliday, Sager, Dungworth and MacDonald (1986) and Gotti (1992), among others, for the scientific register.
} 
Graph 1. Commerce and finance nouns for each sub-period

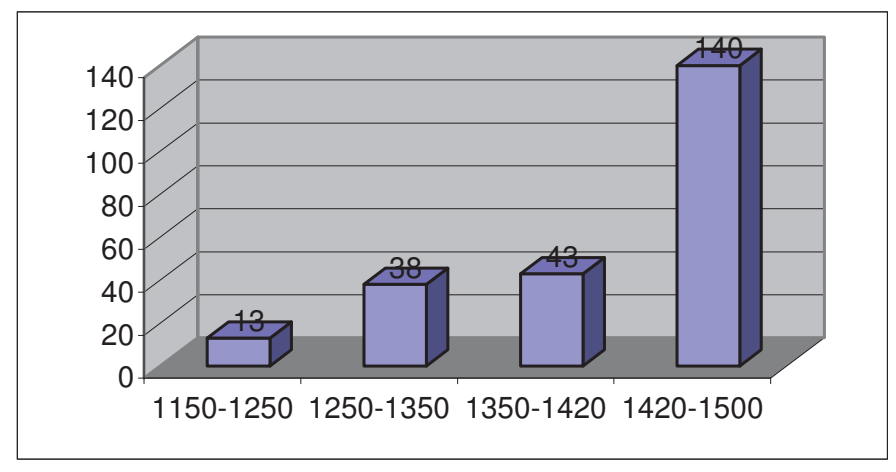

Notwithstanding, its presence is not uniform throughout the Middle Ages: as might have been expected, only 13 occurrences $(5.5 \%$ of all the nouns examined) were identified in ME1 (feor, mede, maðmes, aht), probably owing, on the one hand, to the fact that it is too early to observe the effects of the reforms introduced by the newcomers (the Normans); changes take time to settle in. On the other hand, the low frequency of terms may due to the fact that most of the texts recorded in this period belong to the religious sphere. The middle centuries of the period (between 1250 and 1420) show a greater balance in terms of the number of occurrences: ME2 contains 38 occurrences, which constitutes $16.24 \%$ of the total number of finance nouns (chaffare, shilling, coustage, gauelinge,tax, pris, arrerage, peni, gold); ME3 contains 43 occurrences or $18.38 \%$ (marchande, rente, cost, welles, eschaunge, purchas, ferthyng, bargaynes). Although at this stage the Normans with their institutions and bureaucratic system were already well established, they were not completely integrated into ordinary Anglo-Saxon life. If the number of terms relating to commerce and finance is not greater, this is because the period was one of social and, therefore, economic instability caused by the constant revolts and political struggles taking place, such as the Barons' War, The Peasants' Revolt, The Black Death and The Hundred Years War. It was the beginning of the end of feudalism. Most remarkable is the number of these nouns contained in the last period: 140 or $59.8 \%$ of the total (mynte, rate, somme, a-countes, payement, tidynges, levy, talliages, taxacions, profit, brybe, purchasour, spense, dokatys, 
debyteyys, fees). This reveals that once the most urgent problems had been solved, there was an increasing concern for social welfare and national prosperity. In a study of socio-economic terms from the twelfth to the eighteenth century Crespo (2002) concludes that the semantic sub-fields of "mercantile finance" and "money" prevailed over others such as "property", "taxation" or "profit". The basis for this conclusion lies, once again, in the interaction between sociohistorical events and language evolution: the period under survey

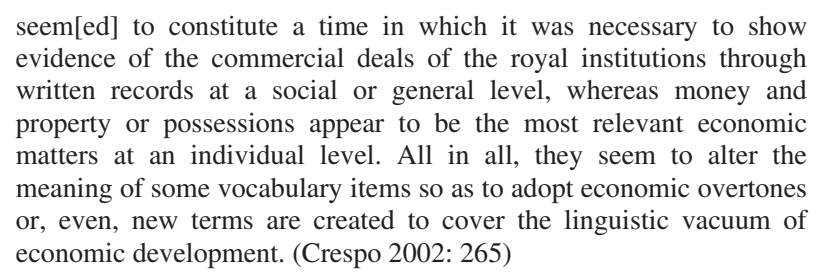

For each of the tokens recorded in our database we have considered different types of information which may reveal something about the history of some of these words. As stated earlier, we examine date and etymological origin in relation to the semantic field of finance and commerce. The information concerning this last aspect has been obtained from the Middle English Dictionary. ${ }^{5}$ All the terms examined have their origins in one of the following source languages: Old English (OE), Old French (OF), Anglo-French (AF), Latin (L), Old Norse (ON), Middle Dutch (MDu) and Middle Latin (ML); and they can all be grouped in two families: Germanic (OE, ON and $\mathrm{MDu}$ ) and Romance (OF, AF, L and ML). Within these two groups the predominant source languages are $\mathrm{OE}$ and $\mathrm{OF}$ but, with the passage of time, a wider range of origins for these financial loanwords is observed, as table 2 below illustrates.

\footnotetext{
${ }^{5}$ Access to the $M E D$ on line has been funded by the Xunta de Galicia, grant number PGIDT 99 PXI $10401 \mathrm{~A}$. This grant is hereby gratefully acknowledged.
} 
112 Isabel Moskowich and Begoña Crespo

Table 2. Etymological origins for ME nouns of finance and commerce

\begin{tabular}{lll}
\hline SUB-PERIOD & ETYMOLOGY & No. \\
\hline $1150-1250$ & OE & 12 \\
& OF & 1 \\
\hline $1250-1350$ & OE & 24 \\
& OF & 12 \\
& AF & 2 \\
$1350-1420$ & OE & 21 \\
& OF & 15 \\
& L & 1 \\
& AF & 5 \\
$1420-1500$ & ON & 1 \\
& OE & 54 \\
& OF & 74 \\
& L & 1 \\
& AF & 6 \\
& MDu & 3 \\
& ML & 2 \\
\hline
\end{tabular}

The same information is displayed in graph 2:

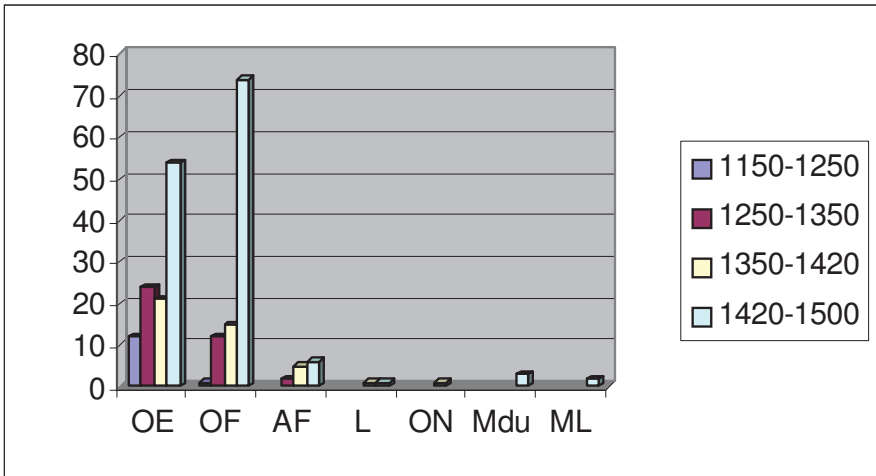

Graph 2. Etymological origins for ME nouns of finance and commerce

Old English is found to be the predominant source language for financial terms at the beginning of the Middle English period (gold, penne, aht) whereas Old French stands out between 1420 and 1500, which is consistent with the provenance of English vocabulary in general (vsure, dette, coin, prouffyte). Once more, the middle centuries 
exhibit a more balanced range of origins; the socio-external explanations adduced for the balanced number of financial nouns during these centuries can also be applied here. The same factors can be argued to account for the presence of one single non-Old English noun between 1150 and 1250 (coste) as opposed to the abundance of non-Old English nouns (83 nouns) between 1420 and 1500. It is also significant that of these 83 loans, 74 belong to OF.

\section{Conclusions}

Our intention in this paper has been to study the extent to which financial terms are present in medieval English texts as well as to identify the etymological origins of those nouns, while referring to the possible socio-external reasons for them.

We know that the Anglo-Saxons maintained commercial relations with neighbouring peoples. However, the evidence from our data suggests that until a certain level of stability was acquired in late Middle English, that intercourse was not manifested linguistically in texts. A closer inspection of these terms also shows that the same historical events may account for the presence of loans belonging to different source languages. The low presence of different languages at the beginning of the period is in marked contrast to their high presence at the end of the period under survey.

It is surprising though, that languages such as $\mathrm{ON}$ and $\mathrm{MDu}$ are only rarely found as sources for loans in the semantic field of our analysis since both the Scandinavian and the Dutch maintained intense commercial relations with the Anglo-Saxons. Two main reasons can be identified for this: firstly, since $\mathrm{OE}$ and $\mathrm{ON}$ share a common Germanic origin it can be difficult to distinguish the actual origin of a particular item (it is easier when there is a divergent phonological evolution in the languages involved). Secondly, some of the terms taken from other Germanic languages probably belong to a nonformal register and would therefore not have been considered as appropriate as Old French ones for use in writing.

We may conclude that, in this particular case, written language does not accurately reflect the social reality. Though we know for certain that commercial exchanges took place primarily between the English and other Germanic-speaking peoples, the vocabulary used in common transactions was not fixed in writing. It 
was the language of those in power that was to be recorded as the vehicle of expression of economic and social growth.

\section{Bibliography}

Anttila, Raimo (ed.). 1989. Historical and Comparative Linguistics. Amsterdam and Philadelphia: John Benjamins Publishing Company.

Bammesberger, Alfred. 1984. English Etymology. Heidelberg: Carl Winter Universitätsverlag.

Baugh, Albert. C. \& Thomas Cable. 1993. A History of the English Language. London: Routledge and Kegan Paul.

Chase, John P. 1988. A Diachronic Semantic Classification of the English Religious Lexis. PhD thesis. Universidad de Glasgow.

Crespo García, Begoña. 1996. 'English and French as $\mathrm{L}_{1}$ and $\mathrm{L}_{2}$ in Renaissance England: A Consequence of Medieval Nationalism' in SEDERI VII: 107114.

2000. 'Historical Background of Multilingualism and its Impact on English' in Trotter, David A. (ed.) Multilingualism in Later Medieval Britain. Cambridge: D. S. Brewer.

2002. 'A Preliminary Approach to the Semantic Analysis of Socio-economic Terms in the History of English' in Quaderni di Semantica XXIII(2): 257272.

De la Cruz Cabanillas, Isabel \& Francisco Javier Martín Arista (eds). 2001. Lingüística histórica inglesa. Barcelona: Ariel.

Fennell, Barbara A. 2001. A History of English. A Sociolinguistic Approach. Oxford: Blackwell Publishers.

Gotti, Maurizio. 1992. 'The Development of a Scientific Language in the Seventeenth Century' in Nocera Avila, Carmela, Nicola Pantaleo \& Domenico Pezzini (eds) Early Modern English: Trends, Forms and Texts. Fasano: Schena editore: $319-343$.

Hughes, Geoffrey. 1988. Words in Time. A Social History of the English Vocabulary. Oxford: Basil Blackwell.

2000. A History of English Words. Oxford: Blackwell Publishers.

Knapp, Peggy A. 2000. Time-bound Words. Semantic and Social Economies from Chaucer's England to Shakespeare's. Basingstoke, Hampshire: Macmillan.

Knowles, Gerry. 1997. A Cultural History of the English language. London: Arnold.

Kurath, Hans et al. 1959-. Middle English Dictionary. On-line at: http://ets.umdl.umich.edu/m/med/ (consulted 28.06.2001).

Machan, Tim W. 2003. English in the Middle Ages. Oxford: OUP.

Millward, Celia M. 1996. A biography of the English language. Fort Worth, Texas: Harcourt Brace College Publishers.

Moskowich-Spiegel Fandiño, Isabel. 1995. Los escandinavos en Inglaterra y el cambio léxico en inglés medieval. A Coruña: UDC Servicio de Publicacións.

. 2002. 'El mito vikingo: el escandinavo como el "otro" en la Inglaterra medieval' in Cuadernos del CEMYR (Centro de Estudios Medievales y Renacentistas, Universidad de la Laguna) 10: 55- 79 
Nevalainen, Terttu \& Helena Raumolin-Brunberg. 2003. Historical Sociolinguistics. London: Longman.

_ 2005. 'Sociolinguistics and the History of English: A Survey' in International Journal of English Studies 5(1): 33-58.

Rissanen, Matti et al. 1991. The Helsinki Corpus of English Texts. The Diachronic Part. Helsinki: Helsinki University Press.

Room, Adrian. 1991. NTC's Dictionary of Changes in Meanings. A Comprehensive Reference to the Major Changes in Meanings in English Words. Lincolwood, Illinois: NTC Publishing Group.

Serjeantson, Mary S. 1935. A History of Foreign Words in English. London: Routledge and Kegan Paul.

Singh, Ishtla. 2005. The History of English. London: Hodder Arnold. 